\title{
Health technology assessment in Canada
}

\author{
Renaldo N. Battista \\ Université de Montréal
}

\section{Brigitte Côté}

Université de Montréal and Agence d'évaluation des technologies et des modes

d'intervention en santé (AÉTMIS)

\author{
Matthew J. Hodge \\ McMaster University
}

\section{Don Husereau}

Canadian Agency for Drugs and Technologies in Health (CADTH)

Canada's health system is a unique combination of public financing and private provision. With the significant government role in financing health services, health technology assessment (HTA) has found a ready audience as a form of policy research. In addition, Canada has been a leader in HTA and is entering a phase of deepening and maturation of $\mathrm{HTA}$ activities. The relative absence of dramatic change in the overall health system, coupled with public faith in the Canadian approach has been favorable to HTA's development in Canada. Emerging issues, beyond the demographic and economic pressures facing all Organisation for Economic Co-operation and Development health systems, include the convergence of assessment modalities and organizations for drug and nondrug technologies, increasing public concerns about the viability of Canada's approach to healthcare services, and the transition of HTA from an activity targeting macro-level policy makers to a management tool for healthcare facilities and providers.

Keywords: Health technology assessment, Canada, History, Future trends

\section{CANADA'S HEALTHCARE SYSTEM}

Since health technology assessment (HTA) in Canada was last reviewed by some of us in 1994 (3), the Canadian healthcare system has evolved and yet remained fundamentally constant. As we noted in the 1994 study, Canada was and remains a sparsely populated country. The population has grown to approximately 32 million people, and 80 percent of the population lives within 320 kilometers of the border with the United States. Despite occupying a landmass of roughly 10 million square kilometers, Canadians are clustered in large cities and their surrounding metropolitan areas.

\section{Founding Principles}

Canada's healthcare system is marked by an enduring combination of public financing and private provision. Public population-wide financing began in 1947 when the province of Saskatchewan established a public universal hospital insurance. At the national level, passage of the Hospital Insurance and Diagnostic Services Act in 1957 led the Government of Canada to negotiate with the provinces to share funding of acute hospital care and laboratory and radiological diagnostic services. By 1961, agreements were in place with all provinces and 99 percent of Canadians had free access to the health services covered by the legislation. However, physician services, notably outpatient services, remained largely uninsured.

In 1964, a Royal Commission on Health Services, chaired by Justice Emmett Hall, recommended a comprehensive and universal medicare system for all Canadians, including coverage of physician care and prescription drugs. By 1966, the majority of Canadians were insured for physician services through various private or public insurance plans. 
Under Canada's federal structure, the thirteen provincial and territorial governments have jurisdiction over the provision of health services and thus, the Canadian "system" consists of thirteen slightly different "systems." All are publicly funded through a combination of provincial government general revenue, specific income-associated health taxes, and transfer payments from the federal government to provincial and territorial governments $(11 ; 18)$. Population coverage for hospital and physician services is universal, contingent on provincial residency requirements of a few months duration, and private insurance companies are functionally banned from providing coverage for services provided through the universal coverage public funding envelope. By and large, coverage of drugs costs for outpatients and long-term care is not included in universal coverage, although all provinces have varying levels of coverage through means-tested programs for drugs and long-term care. This unique approach has generally fostered equitable access to services, but inequity may be growing as the number of uninsured or delisted services grows (33).

\section{Health System Institutions and Constituencies}

Hospitals are not-for-profit organizations and not civil service institutions, but the single-payer system coupled with global budgeting for many hospital services, creates a functionally monopsonistic market for hospital services. Hospital-based healthcare workers, with the exception of physicians, are employed by these hospitals, although their working conditions are often determined through province-wide collective bargaining.

Physicians are compensated through a range of methods but, with few exceptions, are contractors. In primary care and outpatient settings, most physicians manage their own "small business medical practice," typically unincorporated, and are paid through an increasingly complex combination of fee-for-service payments (i.e., volume-dependent) and some form of capitation or rostering payment (12). Hospital-based physicians function in much the same way, sometimes receiving reduced cost or free office space and/or other infrastructure access from hospitals in return for practicing at that facility. Very few physicians are employed by hospitals; thus, many hospitals are dependent upon relatively unstructured relationships with physicians to deliver the care demanded by the communities they serve.

In 1994, we noted that Canada's healthcare system seeks to achieve a balance among government direction, consumer choice, and provider autonomy (3). This quest for balance persists, reflecting the continued application of the Canada Health Act of 1984, which reaffirmed five principles that must be respected by provinces receiving federal cash transfers for health care: public administration, comprehensiveness, universality, portability, and accessibility.

\section{Evolution Amid Constancy: Factors Shaping the System's Evolution}

Given that the system's foundational aspects have changed relatively little, "evolution amid constancy" describes ongoing managed tensions in balancing government direction, consumer choice, and provider autonomy. These "evolutions" include how government exerts direction, consumer attitudes, and provider context.

Over the past two decades, all provincial governments have implemented some version of regionalization (27). These range from establishing relatively weak regional planning bodies to more powerful regional service delivery organizations that group and subsume individual hospitals and other facilities. Alberta introduced a bold move in 2008 with the formation of a single health board, to replace nine regional health authorities, with responsibility for health services delivery for the province as a whole. Proponents of regionalization cite the benefits of coordinated care, volume purchasing, reduced duplication of services, and reduced direct political control of allocation decisions while skeptics tend to point to promised yet unrealized "savings" and the continued politicization of decision making in regional health authorities as evidence that regional bodies have failed to deliver the results claimed for them (34). In addition, some provinces have established variously named "quality councils" intended to report to the public on how the system is functioning. These changes can both be understood either as a dilution of the role of the government in directing the system or more cogently as an upstream move from the State as planner and service provider to the State as steward for the effective allocation of resources in health.

As everywhere, Canadian consumer attitudes toward health, health care, and health technologies are shaped by media. In Canada, proximity to the United States coupled with widespread availability of television originating in the United States creates an additional level of media influence. Despite the geographic proximity, however, such innovations as direct-to-consumer advertising for health technologies are far less widespread (and in some cases, prohibited) in Canada than in the United States. Distinct from the United States, the high importance that Canadians attach to health care is manifest in its consistent high profile in provincial and even federal politics. Perhaps the greatest change has been an increase in the proportion of Canadians expressing concern about the system's productivity (17) and sustainability through the 1990s (13), and a concomitant intensification of consumer vigilance that they and their family members can receive services to which they believe they are entitled. At the bedside or clinic level, relatively high levels of dissatisfaction have been reported among Canadian nurses, not dissimilar to the ones reported in other English-speaking Organisation for Economic Co-operation and Development health systems (1).

At the societal level, several provincial governments have faced legal challenges regarding waiting times for care. 
Likely the most prominent has been the Chaoulli case in Quebec, decided by the Canadian Supreme Court in 2005. Dr. Chaoulli applied for a license from the Government of Quebec to provide services as an independent private hospital, effectively challenging a provincial legislative prohibition on private medical insurance. His request was denied, and he sought legal redress. The Supreme Court of Canada, in a complex 4-3 decision, ruled that the Quebec Health Insurance Act and the Hospital Insurance Act violated citizens' rights under the Quebec Charter of Human Rights and Freedoms and as such were rendered invalid (9). The Government of Quebec argued successfully for a stay of 12 months and subsequently introduced legislation permitting private insurance for selected surgical procedures. The longer-term implications of this decision remain to be seen.

For providers, the evolution of the system has important discipline-specific effects. Canada faces a nursing shortage that has been managed by means of a combination of substitution of other personnel for nursing work and skill-based immigration from developing countries (6). For physicians, the situation is complicated by the difficulty in establishing an optimal doctor-population ratio. Decisions made in the early 1990s to reduce medical school enrollment (2) have been reversed in the face of a perceived "doctor shortage," which has also facilitated a loosening of restrictions on foreigntrained physicians being able to pursue licensure in Canada and a decline in the flow of Canadian physicians to the United States (7). Taken as a whole, the relationship between physicians and provincial governments appears to have evolved away from a narrow conditions-of-work negotiation, despite the absence of an employee-employer relationship with government, to one of shared accountability for the continued availability of physician services.

\section{Mechanisms Modulating Technology Introduction and Use}

The foundation of universal, public financing of privately provided services has shaped both the introduction of technologies and the evolution of HTA in Canada. This macrolevel structural persistence of a single-payer publicly funded system buttressed by legislated impediments to private insurance has long functioned as a form of implicit HTA (14). Because provincial governments designate global funding envelopes for hospitals (or regional health authorities), new hospital construction can only occur with the blessing of government, including the designation of a global budget for any new facility. Furthermore, existing hospitals, while potentially able to raise capital funds through development efforts, must negotiate for the inclusion of operating costs associated with health technologies in their global budget. As a first approximation, public financing by means of global budgeting, coupled with filled-to-capacity hospitals, appears to have blunted competitive desires of hospitals to outdo each other with the latest technologies as has been seen in other health systems, notably the United States, because such a strategy is likely to be financially unsustainable.

Nevertheless, by the early 1990s, virtually all provinces were considering or introducing additional measures to manage technology adoption and use. This occurred at different rates in different provinces but emerged from a shared recognition of the bluntness of global budgeting as a "technology assessment/management" tool. In the larger provinces, the establishment of specific HTA bodies, typically at some distance from the policy process but intended to provide input to that process, was the most obvious of these responses.

For lower cost technologies, physician influence has been a more important determinant of diffusion (4). This is particularly the case for those technologies (e.g., certain point of care devices) whose costs can be passed on to patients/consumers by means of direct billing. However, the relative undersupply of doctors, the majority of whom are in primary care settings, may have limited the entrepreneurial willingness of individual physicians to invest in free-standing, physician-owned alternatives to hospital-provided care for such technologies as endoscopy and diagnostic imaging. Moreover, in some provinces, the designation of separate professional fees (for the doing of a procedure and/or its interpretation) and technical fees (for the equipment and infrastructure costs) with the technical fee paid only in facilities to which the government has granted a permit, may explain the relatively low levels of physician-driven diffusion of technologies compared with other health systems with private provision of services.

\section{EARLY HISTORY OF HTA}

HTA in Canada emerged in a relatively favorable environment due to the convergence of several factors. These include a positive predisposition of clinicians, patients, and managers toward health science, and likely the paucity of Canada-based developers and producers of health technologies. Although the situation is somewhat less simple with pharmaceuticals, Canada's historically low levels of expenditure on research and development, coupled with the proximity of the United States, so that new technologies are available relatively quickly, meant that HTA could emerge as policyrelevant research to assist governments in spending public resources optimally, rather than as an adjudication mechanism between promoters of technologies and those expected to pay their costs.

The first Technology Assessment body in Canada was established in Quebec in 1988, following a gestation period initiated in the mid-1970s. The Conseil d'évaluation des technologies de la santé (CÉTS) was created by the Quebec government to promote, support, and produce assessments of health technologies, to counsel the Minister and all the key stakeholders of the health system. The impact of the CÉTS was documented $(20 ; 21)$, and the CÉTS became the Agence 
d'évaluation des technologies et des modes d'intervention en santé (AÉTMIS), in 2000.

The national Canadian Coordinating Office for Health Technology Assessment (CCOHTA) was created in 1989 following an interprovincial symposium held in Quebec City (35). This followed studies of technology diffusion and calls in the mid-1980s to move ahead on health technology assessment $(10 ; 15)$. Pan-Canadian efforts on nondrug technologies were, as in many other fields of primarily provincial jurisdiction, modestly funded, relatively low profile, and focused primarily on coordination so as to avoid offending larger provinces while capturing some of the "public good" aspects for the benefit of smaller provinces whose capacity was and remains limited. However, CCOHTA saw an important broadening of its mandate in recent years encompassing HTA, common drug review and optimal medication prescribing and utilization (32). CCOHTA became the Canadian Agency for Drugs and Technologies in Health (CADTH) in 2006.

The British Columbia Office of Health Technology Assessment (BCOHTA) was established in 1990 by a grant to the University of British Columbia from the Province, to promote and encourage the use of assessment research by government, healthcare executives, and practitioners. It sought to examine more specifically the interactions of health technology with society. Government funding for BCOHTA ceased in 2002 when government made major cuts to its operating budget (23).

A Health Technology Assessment Program was established within the Alberta Department of Health in 1993 and then transferred to the Alberta Heritage Foundation for Medical Research in 1995. It was transferred to the Institute of Health Economics (IHE) in 2006 where it is currently situated $(5 ; 22)$.

\section{EVOLUTION OF HTA AND EMERGING TRENDS}

\section{HTA Organizations}

In addition to the growth in the number of HTA organizations, the culture of HTA has diffused relatively rapidly across Canada. Federal Commissions assessing the future of "Medicare" have generally recommended increasing resources for HTA and advised decision makers to increase the influence of HTA in decision making (24;31). Differences among provincial and territorial jurisdictions in delivering health services across Canada are reflected in the differences among organizations conducting HTA. As presented in Table 1, several models exist resulting from varying combinations of major affiliation, scope and breadth of the assessments, and targeted decision makers.

HTA organizations can be supported by government (quasigovernmental), operate within government, develop within an academic setting or within a hospital.
The quasigovernmental institution is a popular model in Canada. CADTH, AÉTMIS, The Health Quality Council in Saskatchewan (which succeeded the Health Services Utilisation and Research Commission), and the Center for Applied Health Research in New Foundland and Labrador are of this form. While funding of these organizations comes in the main from government, their margin of autonomy is important.

The Ontario Health Technology Advisory Committee (OHTAC) is managed and staffed by government and the work plan is largely driven by hospitals and the Ministry of Health and Long-Term Care (26). OHTAC is currently leading several field evaluations of promising health technologies in partnership with clinical and academic research institutions.

Several academic centers have developed an important research capacity in Health Technology Assessment, among them the Institute for Clinical Evaluative Sciences (ICES) established in 1992 (19), and more recently, three EvidenceBased Practice Centers that conduct assessments in partnership with the Agency for HealthCare Research and Quality in the United States.

The emergence of hospital-based technology assessment efforts can be seen as evidence of the embedding of HTA as a permanent feature in decision making about health technologies in Canada. For example, the Greater Victoria Hospital Society introduced such a process in the early 1990s (22), whereas Academic Health Centers in Quebec are now required to develop an HTA capacity (28).

Recent developments in Quebec highlight the increasing scope of the HTA effort, bringing both drugs and devices together and taking a broader view of "technologies," with the proposed creation of INESSS (Institut national d'excellence en santé et en services sociaux). This effort is modeled in part on the National Institute for Health and Clinical Excellence (NICE) in the United Kingdom, but the inclusion of social services is a novel extension of the effort to expand the influence of HTA and HTA-like efforts. Whether this represents a harmonious joining of related approaches remains to be determined, but it does suggest a maturation of the tools of HTA work.

\section{Emerging Trends Shaping Technology Use and HTA}

In 1994, one could reasonably conclude that, in all eight countries surveyed, HTA organizations were developing organizational structures and relations to health system actors that reflected the particular characteristics of each country's health system. The situation in Canada suggests that the evolution of HTA in Canada since that report has also been conditioned by the changes in Canada's approach to health policy, financing, and service provision, characterized as evolution amid constancy rather than radical change. HTA has clearly matured, as evident by its increasingly prominent role in government decision making as governments move, albeit by fits 
Table 1. Organizations Conducting HTA in Canada

\begin{tabular}{|c|c|c|c|c|}
\hline Province/HTA producer & Year & Where & What technology & To whom \\
\hline Alberta & 1995 & 1) Academic coalition & Drugs & Provincial \\
\hline $\begin{array}{l}\text { 1) Health technology assessment } \\
\text { program/Institute of Health economics } \\
\text { (IHE) }\end{array}$ & & & $\begin{array}{l}\text { Treatment and devices, Complex } \\
\text { (modes) of intervention, } \\
\text { Practices, Policies }\end{array}$ & \\
\hline $\begin{array}{l}\text { 2) Capital Health Office for Health } \\
\text { Innovation }\end{array}$ & 2005 & 2) Regional & $\begin{array}{l}\text { Treatment and devices, Complex } \\
\text { (modes) of intervention, } \\
\text { Practices, Policies }\end{array}$ & Health region \\
\hline $\begin{array}{l}\text { 3) Alberta Health Technology } \\
\text { Assessment Coalition (AHTAC) }\end{array}$ & 2005 & 3) Academic coalition & $\begin{array}{l}\text { Drugs, Treatment and devices, } \\
\text { Complex (modes) of } \\
\text { intervention, Practices }\end{array}$ & Provincial Hospital \\
\hline $\begin{array}{l}\text { 4) University of Alberta/Capital Health } \\
\text { Evidence-Based Practice Center (EPC) }\end{array}$ & 2002 & 4) Regional & $\begin{array}{l}\text { Drugs, Treatment and devices, } \\
\text { Complex (modes) of } \\
\text { intervention, Practices }\end{array}$ & $\begin{array}{l}\text { Health region partnership with } \\
\text { Agency for Healthcare } \\
\text { Research and Quality } \\
\text { (AHRQ) }\end{array}$ \\
\hline $\begin{array}{l}\text { 5) University of Calgary/The Institute for } \\
\text { Advanced Policy Research (IAPR) }\end{array}$ & 2004 & 5) Academic & Policy & Provincial \\
\hline $\begin{array}{l}\text { 6) Calgary Health Region/Foothills } \\
\text { Medical Center/Department of Surgery }\end{array}$ & 2005 & 6) Hospital-based & $\begin{array}{l}\text { Surgical technologies } \\
\quad \text { (equipment or procedure) } \\
\text { (new, replacement or upgrade) }\end{array}$ & Health region Hospital \\
\hline British Columbia & 1994 & Academic & Drugs & Provincial Ministry \\
\hline $\begin{array}{l}\text { 1) Therapeutics Initiative } \\
\text { 2) Innovation in Health Technology }\end{array}$ & 2006 & Regional & Innovation & Regional Health Authority \\
\hline $\begin{array}{l}\text { Manitoba } \\
\text { 1) Manitoba Centre for Health Policy } \\
\text { (MCHP) }\end{array}$ & 1991 & Academic & $\begin{array}{l}\text { Complex interventions, } \\
\text { Practices, Policy }\end{array}$ & Provincial Ministry \\
\hline New Brunswick & None & & & \\
\hline $\begin{array}{l}\text { New Foundland and Labrador } \\
\text { 1) New Foundland and Labrador Center } \\
\text { for Applied Health Research }\end{array}$ & 1999 & Quasigovernmental & $\begin{array}{l}\text { Drugs, Treatment and devices, } \\
\text { Complex (modes) of } \\
\text { intervention, Practices, } \\
\text { Policies, }\end{array}$ & Provincial Health Region \\
\hline $\begin{array}{l}\text { Nova Scotia } \\
\text { 1) Capital health drug evaluation } \\
\text { unit/Drug Evaluation Alliance of Nova } \\
\text { Scotia (DEANS)/Dalhousie University }\end{array}$ & 1998 & Academic coalition & Drugs, Practice, Policy & $\begin{array}{l}\text { Provincial Health Region } \\
\text { Practice }\end{array}$ \\
\hline \multicolumn{5}{|l|}{ Ontario } \\
\hline $\begin{array}{l}\text { 1) Ontario Health Technology Advisory } \\
\text { Committee (OHTAC) and Medical } \\
\text { Advisory Secretariat (MAS) }\end{array}$ & 2003 & 1) Government & $\begin{array}{l}\text { Drugs, Treatment and devices, } \\
\text { Complex (modes) of } \\
\text { intervention, Practices, } \\
\text { Policies }\end{array}$ & $\begin{array}{l}\text { Provincial Health Region } \\
\text { Hospital }\end{array}$ \\
\hline $\begin{array}{l}\text { 2) Institute for Clinical Evaluative } \\
\text { Sciences (ICES) }\end{array}$ & 1992 & 2) Academic & $\begin{array}{l}\text { Drugs, Treatment and devices, } \\
\text { Complex (modes) of } \\
\text { intervention, Practices, } \\
\text { Policies }\end{array}$ & Provincial Practice \\
\hline $\begin{array}{l}\text { 3) London Health Sciences center/High } \\
\text { Impact Technology Evaluation (HiTec) }\end{array}$ & 2004 & 3) Hospital-based & $\begin{array}{l}\text { Drugs, Treatment and devices, } \\
\text { Complex (modes) of } \\
\text { intervention, Practices, } \\
\text { Policies }\end{array}$ & Hospital \\
\hline $\begin{array}{l}\text { 4) Evidence-Based Practice } \\
\text { Center/University of Ottawa }\end{array}$ & 2002 & 4) Hospital-based & Drugs, Treatment and devices & $\begin{array}{l}\text { Hospital Practice Partnership } \\
\text { with Agency for Healthcare } \\
\text { Research and Quality } \\
\text { (AHRQ) }\end{array}$ \\
\hline $\begin{array}{l}\text { 5) Evidence-Based Practice Center } \\
\text { (EPC)/McMaster University }\end{array}$ & 1997 & 5) Academic coalition & $\begin{array}{l}\text { Complex (modes) of } \\
\text { intervention, Practices, } \\
\text { Policies, Drugs, Treatment and } \\
\text { devices, Complex (modes) of } \\
\text { intervention, Practices, } \\
\text { Policies }\end{array}$ & $\begin{array}{l}\text { Provincial Hospital Practice } \\
\text { partnership with Agency for } \\
\text { Healthcare Research and } \\
\text { Quality (AHRQ) }\end{array}$ \\
\hline $\begin{array}{l}\text { 6) Programs for Assessment of } \\
\text { Technology in Health } \\
\text { (PATH)/McMaster University }\end{array}$ & 2003 & 6) Academic & $\begin{array}{l}\text { Drugs, Treatment and devices } \\
\text { Complex (modes) of } \\
\text { intervention, Practices, } \\
\text { Policies }\end{array}$ & Provincial \\
\hline
\end{tabular}


Table 1. Continued

\begin{tabular}{|c|c|c|c|c|}
\hline Province/HTA producer & Year & Where & What technology & To whom \\
\hline $\begin{array}{l}\text { 7) Toronto Health Economics and } \\
\text { Technology Assessment Collaborative } \\
\text { (THETA)/University of Toronto }\end{array}$ & 2007 & 7) Academic coalition & Drugs, Treatments & Provincial \\
\hline $\begin{array}{l}\text { 8) Technology Assessment at Sick Kids } \\
\text { (TASK)/Toronto Sick Kids Hospital }\end{array}$ & 2007 & 8) Hospital-based & $\begin{array}{l}\text { Drugs, Treatment and } \\
\text { devices, Complex (modes) } \\
\text { of intervention, Policies }\end{array}$ & Hospital \\
\hline Prince Edward Island & None & & & \\
\hline $\begin{array}{l}\text { Quebec } \\
\text { 1) Agence d'évaluation des technologies et } \\
\text { des modes d'intervention en santé } \\
\text { (AÉTMIS) (successor of CÉTS) }\end{array}$ & 1988 & 1) Quasigovernmental & $\begin{array}{l}\text { Drugs, Treatment and } \\
\text { devices, Complex (modes) } \\
\text { of intervention, Practices, } \\
\text { Policies }\end{array}$ & Provincial \\
\hline 2) Conseil du médicament & 1988 & 2) Quasigovernmental & Drugs & Provincial \\
\hline $\begin{array}{l}\text { 3) Technology Assessment Unit (TAU) } \\
\text { McGill University Health Center } \\
\text { (MUHC) }\end{array}$ & 2002 & 3) Hospital-based & $\begin{array}{l}\text { Drugs, Treatment and } \\
\text { devices } \\
\text { Practices, Policies }\end{array}$ & Hospital \\
\hline $\begin{array}{l}\text { 4) Unité d'évaluation des technologies et } \\
\text { des modes d'intervention en santé } \\
\text { (UETMIS)/Centre hospitalier } \\
\text { universitaire de Sherbrooke (CHUS) }\end{array}$ & 2005 & 4) Hospital-based & $\begin{array}{l}\text { Treatment and devices, } \\
\text { Practices }\end{array}$ & Hospital \\
\hline $\begin{array}{l}\text { 5) Direction de l'évaluation des } \\
\text { technologies et des modes d'intervention } \\
\text { en santé/Centre hospitalier universitaire } \\
\text { de l'Université de Montréal (CHUM) }\end{array}$ & 2005 & 5) Hospital-based & $\begin{array}{l}\text { Treatment and devices, } \\
\text { Practices }\end{array}$ & Hospital \\
\hline $\begin{array}{l}\text { 6) UETMIS/Centre hospitalier universitaire } \\
\text { Sainte-Justine (CHU Sainte-Justine) }\end{array}$ & 2005 & 6) Hospital-based & $\begin{array}{l}\text { Treatment and devices, } \\
\text { Practices }\end{array}$ & Hospital \\
\hline $\begin{array}{l}\text { 7) UETMIS/Centre hospitalier universitaire } \\
\text { de Québec (CHUQ) }\end{array}$ & 2005 & 7) Hospital-based & $\begin{array}{l}\text { Treatment and devices, } \\
\text { Practices }\end{array}$ & Hospital \\
\hline $\begin{array}{l}\text { Saskatchewan } \\
\text { Health Quality Council (HQC) }\end{array}$ & 2002 & Quasigovernmental & $\begin{array}{l}\text { Treatments, Practices, } \\
\text { Drugs, Complex } \\
\text { interventions }\end{array}$ & $\begin{array}{l}\text { Provincial Health Regional } \\
\text { Practice }\end{array}$ \\
\hline \multicolumn{5}{|l|}{ National level } \\
\hline 1) HTA drugs and devices & 1989 & 1) Quasigovernmental & $\begin{array}{l}\text { 1) Drugs, Treatment and } \\
\text { devices, Complex } \\
\text { (modes) of intervention }\end{array}$ & $\begin{array}{l}\text { 1) National, Provincial, } \\
\text { Health Region, Hospital }\end{array}$ \\
\hline 2) Common Drug Review (CDR) & & & 2) Drugs, Policies & 2) National \\
\hline 3) Canadian Optimal Medication & & & 3) Drugs, Practice & 3) National \\
\hline $\begin{array}{l}\text { Prescribing \& Utilization Service } \\
\text { (COMPUS) }\end{array}$ & & & & \\
\hline $\begin{array}{l}\text { Applied research and analysis Directorate } \\
\text { (ARAD)/Health Canada }\end{array}$ & $1999 / 200$ & Government & Drug Policy & $\begin{array}{l}\text { National Ministry of } \\
\text { Health }\end{array}$ \\
\hline
\end{tabular}

and starts, to strengthen their stewardship role and reduce direct engagement in allocation decisions. Health technology policy issues are now discussed at a National Health Technology Strategy Policy Forum. CADTH has also introduced an inquiry response service and liaison program, to facilitate the exchange of HTA information across its member provinces. This gradualism and continued growth in resource allocations to healthcare delivery may explain why Canadian consumers appear to have been largely unaware of the impacts of HTA.

From a system perspective, one of HTA's effects appears to have been "managed diffusion" of health technologies (23). By offsetting a politically acceptable delay to technology introduction with more information, and ensuring that the HTA process had the imprimatur of academic rigor, provincial governments as payers may have benefitted from falling unit costs available to later adopters (associated with increased production and competition from similar products) as well as risk mitigation by not being an early adopter (30). However, in the longer-term, a more reasoned approach to the introduction of innovation is becoming part of the decisionmaking culture in Canada.

For consumers, proximity to the United States has and continues to afford an alternative in two important ways: an object lesson in the perils of market-driven technology diffusion for those who favor the Canadian approach and a nearby, market-priced alternative for those who wish to exercise their consumer sovereignty more freely. Rapid shifts, perhaps driven by demographic pressure from the affluent, 
aging postwar generation, have yet to engender a move away from public financing. Should that change, many of the tools and insights of HTA, notably cost-effectiveness, which were new to government in the 1990s, would likely be adopted without comment by profit-motivated healthcare organizations as part of modern management of a complex healthcare enterprise. Any notion of societal discourse or contextualization process regarding health technologies will almost certainly be drowned out by what would likely be a vigorous debate about the merits of changing the foundational aspects of the Canadian healthcare system $(25 ; 29)$.

The divergence between the policy response to pharmaceuticals and that to health technologies seems worthy of further investigation. The common drug review process, which is in part led by CADTH, in which all provinces except Quebec collaborate, has been markedly more developed than national-level collaboration in HTA more broadly (8). Among the factors that may explain this observation are a political response to a more concentrated industry presence ("pharma" is more clearly understood and better organized than "health technology industry"), readily discernible costs (drugs spending is relatively easily identified within provincial health spending), and the relative lack of complex "care production processes" involving pharma products as compared to technology more broadly, which makes costeffectiveness calculations more straightforward for pharmaceuticals. Fairly or not, pharmaceuticals are typically perceived as "simple" and context-free interventions (i.e., patient takes pill) rather than complex interventions such as diagnostic imaging (i.e., patient has imaging study whose interpretation may trigger further technology use that unfolds over longer periods of time before definitive outcome occurs).

The future of HTA in Canada suggests a further deepening of its academic roots in applied health research as government decision makers have begun to embrace decisionmaking frameworks which incorporate primary data gathering (16). This is a departure from a previous artificial separation of healthcare policy and publicly funded academic research. Indeed, there is potential in enhancing greater convergence between HTA organizations, funding organizations such as the Canadian Institutes for Health Research (CIHR) and the Canadian Health Services Research Foundation (CHSRF), public health, and the academically led evidencebased movement. Such a convergence would strengthen and increase training capacity in HTA.

Conditional reimbursement schemes have allowed public payers to satisfy consumer-driven (and manufacturerdriven) needs for access to new technologies while at the same time reducing the uncertainty in public policy decisions. Although a national health technology strategy has been developed and describes a coordinated approach to collecting further information through policy studies, its implementation will require the collective resolve of the provinces delivering health care.

\section{CONCLUSION}

Canada has been a vigorous supporter and user of HTA with a multiplication of HTA organizations across the country. HTA's influence has been most identifiable by means of the inputs of HTA organizations into the policy process at provincial government levels, but increasingly, hospitals are developing HTA competencies and capacity. Public engagement has been modest and the overarching policy environment of Canada's health system is such a significant determinant of the system's functioning and the use and diffusion of technologies that practitioners and individual providers have been relatively unengaged and arguably only indirectly affected by HTA. If HTA is to deepen its influence in the Canadian context, it will be essential to ensure that HTA is an active player in two forms of "linking-up." The first of these is linking practitioners and providers to information, not only in the classic "evidence-based medicine/knowledge transfer" sense, but also with regular, even real-time, feedback on outcomes and comparative performance. The second is a form of health system "middleware" that can recraft the patient experience away from the current approach with silos of primary care, hospital, and long-term care to one with a more seamless transition of care, information, and yielding better outcomes and ideally, slowed cost growth. HTA's traditional policy-level focus in Canada will need to broaden to ensure its continued relevance, particularly if evolution amid constancy is replaced by dramatic change in the foundational aspects of Canada's health system.

\section{CONTACT INFORMATION}

Renaldo N. Battista, MD, ScD (Renaldo.battista@ umontreal.ca), Professor, Department of Health Administration, Université de Montréal, P.O. Box 6128, Station Centre Ville, Montreal, Quebec H3C 3J7, Canada

Brigitte Côté, MD, MSc (Brigitte.cote@aetmis.gouv.qc.ca), Adjunct Professor, Department of Health Administration, Université de Montréal, CP 6128, succ. Centre-Ville, Montréal, Quebec, H3C 3J7, Canada; Researcher, Agence d'évaluation des technologies et des modes d'intervention en santé (AÉTMIS), 2021 Union, Montreal, Quebec H3A 2S9, Canada

Matthew J. Hodge, MDCM, PhD (hodge@unfpa.org), Adjunct Professor, Clinical Epidemiology \& Biostatistics, McMaster University, 1200 Main Street West, Hamilton, Ontario L8N 3Z5, Canada

Donald R. Husereau, BSc, MSc (donh@cadth.ca), Director, Project Development, Department of Health Technology Assessment, Canadian Agency for Drugs and Technologies in Health (CADTH), 600-865 Carling Avenue, Ottawa, Ontario K2S 5S8, Canada 


\section{ACKNOWLEDGMENTS}

The authors thank Robert Jacob, Donald Juzwishin, Arminee Kazanjian, and Louise Lafortune for their comments and suggestions on earlier drafts of this study.

\section{REFERENCES}

1. Aiken LH, Clarke SP, Sloane DM, et al. Nurses' reports on hospital care in five countries. Health Aff (Millwood). 2001;20:4353.

2. Barer ML, Stoddart GL. Toward integrated medical resource policies for Canada. Ottawa: Federal/Provincial/Territorial Conference of Deputy Ministers of Health; 1991.

3. Battista RN, Jacob R, Hodge MJ. Health care technology in Canada (with special reference to Quebec). Health Policy. 1994;30:73-122.

4. Battista RN, Lance JM, Lehoux P, Régnier G. Health technology assessment and the regulation of medical devices and procedures in Quebec. Synergy, collusion, or collision? Int J Technol Assess Health Care. 1999;15:593-601.

5. Borowski HZ, Brehaut J, Hailey D. Linking evidence from Health Technology Assessments to policy and decision making: The Alberta model. Int J Technol Assess Health Care. 2007;23:155-161.

6. Canadian Institute for Health Information. Measuring the retention of registered nurses in Canada: A study of 2000-2004 registration data. Ottawa, ON: CIHI; 2006.

7. Association of Faculties of Medicine of Canada. Canadian medical education statistics 2008. Ottawa: Association of Faculties of Medicine of Canada; 2008.

8. Canadian Agency for Drugs and Technologies in Health. Common drug review. http://cadth.ca/index.php/en/cdr. (accessed December 5, 2008).

9. Cour suprême du Canada (2005), Chaoulli c. Quebec, CSC $_{35}$.

10. Deber RB, Thompson GG, Leatt P. Technology acquisition in Canada. Control in a regulated market. Int J Technol Assess Health Care. 1988;4:185-206.

11. Detsky AS, Naylor CD. Canada's health care system-reform delayed. N Engl J Med. 2003;349:804-810.

12. Devlin RA, Sarma S. Do physician remuneration schemes matter? The case of Canadian family physicians. J Health Econ. 2008;27:1168-1181.

13. Donelan K, Blendon RJ, Schoen C, Davis K, Binns K. The cost of health system change: Public discontent in five nations. Health Aff (Millwood). 1999;18:206-216.

14. Evans RG. The fiscal management of medical technology: The case of Canada. In: Banta HD, ed. Resources for health: Technology assessment for policy-making. New York: Praeger; 1982:178-199.

15. Feeny D, Guyatt G, Tugwell P, eds. Health care technology: Effectiveness, efficiency and public policy. Montreal: The Institute for Research on Public Policy; 1986:270.

16. Goeree R, Levin L. Building bridges between academic research and policy formulation: The PRUFE framework - an integral part of Ontario's evidence-based HTPA process. Pharmacoeconomics. 2006;24:1143-1156.
17. Health Council of Canada. (2008). Rekindling reform: Health care renewal in Canada, 2003-2008. Toronto: Health Council. www.healthcouncilcanada.ca.

18. Iglehart JK. Revisiting the Canadian health care system. $N$ Engl J Med. 2000;342:2007-2012.

19. Institute for Clinical Evaluative Sciences. World-class research. Real world results. 16th Annual Report, 2008. www.ices.on.ca.

20. Jacob R, Battista RN. Assessing technology assessment: Early results of the Quebec experience. Int J Technol Assess Health Care. 1993;9:564-572.

21. Jacob R, McGregor M. Assessing the impact of health technology assessment. Int J Technol Assess Health Care. 1997;13:6880 .

22. Juzwishin D. Framework for regional Health authorities to make optimal use of health technology assessment. Alberta Heritage Foundation for Medical Research, 2000. http://www.ihe.ca/documents/HTA-FR.1.PDF.

23. Kazanjian A, Green CJ. Health technology assessment within a public accountability framework. Clin Governance. 2004;9:5158.

24. Kirby MJL, (Chair). The health of Canadians - The Federal role. The Standing Senate Committee on Social Affairs, Science and Technology; 2002.

25. Lehoux P, Tailliez S, Denis JL, Hivon M. Redefining health technology assessment in Canada: Diversification of products and contextualization of findings. Int J Technol Assess Health Care. 2004;20:325-336.

26. Levin L, Goeree R, Sikich N, et al. Establishing a comprehensive continuum from an evidentiary base to policy development for health technologies: The Ontario experience. Int J Technol Assess Health Care. 2007;23:299-309.

27. Lewis S, Kouri D. Regionalization: Making sense of the Canadian experience. Healthc Pap. 2004;5:12-31.

28. McGregor M, Brophy JM. End-user involvement in health technology assessment (HTA) development: A way to increase impact. Int J Technol Assess Health Care. 2005;21:263-267.

29. Menon D, Stafinski T. Engaging the public in priority-setting for health technology assessment: Findings from a citizens' jury. Health Expect. 2008;11:282-293.

30. Philips Z, Claxton K, Palmer S. The half-life of truth: What are appropriate time horizons for research decisions? Med Decis Making. 2008;28:287-299.

31. Romanow RJ, (Commissioner). Building on values - The future of health care in Canada. Saskatoon: Commission on the Future of Health Care in Canada; 2002.

32. Sanders JM. Challenges, choices and Canada. Int J Technol Assess Health Care. 2002;18:199-202.

33. Schoen $\mathrm{C}$, Doty MM. Inequities in access to medical care in five countries: Findings from the 2001 Commonwealth Fund International Health Policy Survey. Health Policy. 2004;67:309322.

34. Smith N, Church J. Shifting the lens: The introduction of population-based funding in Alberta. Healthc Manage Forum. 2008;21:36-42.

35. Symposium sur l'évaluation des technologies de la santé. Gouvernement du Québec, Ministère de la santé et des services sociaux, Québec, 25-26 mai 1989. 